\title{
Evaluative Comparison Of Palm Wine Analogue And Oil Palm Wine
}

I. J. Dioha*, M.O. Agho and A.S. Sambo

Chemistry Programme, Abubakar Tafawa Balewa University, Bauchi, Nigeria.

\begin{abstract}
Various analyses and sensory evaluation of palm wine analogue and oil palm wine have been carried out. Important parameters such as physicochemical properties, nutritive values, phytochemical screening and microbiological analysis of the two brands of wines were assessed. The results show that the wines have similar properties with insignificant variations in their values. Sensory evaluation with t-test showed that there was no significant difference $(P=0.05$ and $P=0.01)$ in colour, odour, effervescence and general acceptability between palm wine analogue and oil palm wine. While there also was no significant difference in the tastes and balance of sweetness at $P=0.01$, a slight difference existed at $P=0.05$.
\end{abstract}

\section{INTRODUCTION}

Palm wine analogue is a brand of wine produced from table sugar via the fermentation reaction. Palm wine is the general name for alcoholic beverages produced from the sap of palm trees. It differs from the grape wines in opacity and colour. Palm wine is usually a whitish, opaque and effervescent liquid, whose properties derive from the fact that there are live organisms in the beverage when it is consumed ${ }^{1}$. The palm wine is obtained from a variety of parts of the palm tree: the stem of the standing tree, the tip or trunk of the felled tree and the base of the immature male inflorescence. The wine produced from the oil palm (Elaeis guineensis) contains about 12\% sucrose, $1 \%$ each of fructose, glucose and raffinose, small quantities of protein and some vitamins ${ }^{2}$. Apparently, most palm sap can yield wine. The most frequently tapped are the coconut palm (Cocos nucifera), the oil palm (Elaeis guineensis), the wild date palm (Boraaus flabellifer), the nipa palm (Nipa fruticans), the raphia palm (Raphia hookeri or $R$. vinifera), and the Kithul palm (Caryota urens). A complete listing of palm species used to make wine is given by Swings ${ }^{3}$.

For the production of natural palm wine, a succession of micro- organisms including gram -negative bacteria, lactic acid bacteria, yeast, and finally acetic acid bacteria may be present. The organisms find their way into the sap of palm trees from a variety of sources including air, tapping utensils with the residue of previous brews, and the trees. The resulting wine has been reported to contain about $3 \%(\mathrm{v} / \mathrm{v})$ alcohol, and it is a rich source of (single cell) protein and various vitamins because of the presence of bacteria and yeast ${ }^{4}$. Spontaneous fermentation is conducted in traditional wine making regions and indigenous yeast, which is mainly wild yeast of the genera, Sacharomyces, Kloekera, Rhodotorula, Crytocococcus, Candida and Pichia is responsible for fermentation 5

Palm wine is most acceptable in West Africa when it is sweet. Preventing acidity and sediment and preserving the sweet flavour, effervescence and milky white colour of stored wine are the major problems that confront the retailers. Several attempts have been made to reach 
these ends so as to always have enough palm wine available. Levi and Oruche ${ }^{6}$ used sodium metabisulphite and sodium benzoate as preservatives to prevent microbial activity. Chinarasa ${ }^{7}$ tried pasteurization but none of these methods and other attempts were completely successful in producing enough palm wine for the consumer. The need therefore arises for alternative source of palm wine to augment the natural supply of palm wine from oil and other palms that yield wine.

Bassir ${ }^{8}$ estimated in 1968 that about 4 million people in Nigeria each consumes about $500 \mathrm{ml}$ of palm wine per day. The number of habitual palm wine consumers has risen to above 8 million people due to increased socialization of the people. The ever increasing number of palm wine consumers has continued to encourage the tapping of oil palm trees which are getting threatened by early extinction.

The Kebbi State of Nigeria forestry Edict 1997 has extensive provision on preservation of forest as its principal aim. Certain trees and plants including oil palm, as contained in schedule 2 of the law, are protected (section 10). Section 25 (2) of the Edict has laid down offences relating to forestry ${ }^{9}$; these offences are up-rooting or burning or, otherwise, damaging any tree, residing in, erecting of a structure, building or camping in a reserve, setting fire without taking necessary precaution or even raising smoke or lighting a fire in a forest reserve etc. The punishment for these offences is five years imprisonment or a fine of one hundred and seven U.S dollar. Oil palm is found in the Northern Guinea Savannah region of Kebbi State where the tapping of it is restricted because of the edict. Creation of an alternative source of palm wine is necessary in this region where some of the consumers reside.

\section{EXPERIMENTAL Preparation of palm wine analogue}

Four litres each of five different concentrations of table sugar solutions ranging from $0.2 \mathrm{M}$ to $0.6 \mathrm{M}$ was prepared in a transparent 4.5 litre plastic container with potable water which has already been analysed. To each of the sugar solutions was added $14 \mathrm{~g}$ of Engendura Brewer's yeast, Saccharomyces cerevisiae. The mixture was shaken after corking the container airtight. The set ups were allowed to stand for 24 hours at room temperature of $30-37{ }^{0} \mathrm{C}$ to ensure optimum yield of wine. The $0.4 \mathrm{M}$ solution was selected because preliminary tests showed that it yielded more of palm wine attributes when used for palm wine production.

The oil palm wine used for the assessment was collected in a sterile white plastic container. The fresh undiluted oil palm wine was collected directly from the tree from Wara in Kebbi State. The analysis of the oil palm wine has been reported by the authors ${ }^{10}$.

\section{Microbiological test}

Nutrient agar was prepared by dissolving $7.0 \mathrm{~g}$ of the agar in $250 \mathrm{ml}$ of distilled water. The solution was also sterilized in an autoclave for 15 minutes and poured into sterilized petridishes and kept in a refrigerator for 24 hours. This was done according to standard microbiology techniques ${ }^{11}$. Then, the petridishes were retrieved, assessed and inoculated with serially diluted palm wine analogue. This was done by streaking the surface of the plates in a zig-zag until all the surface was rubbed. The inoculated plates were incubated for 24 hours at $37^{\circ} \mathrm{C}$. Gram staining was done according to standard procedure ${ }^{12}$ so as to identify cultured organisms to differentiate between gram-positive and gram-negative bacteria. 


\section{Phytochemical tests}

The tests for alkaloids, tannins, saponins and cardiac glycosides were carried out according to standard procedure $^{13}$.

\section{Tests}

\section{Alkaloids}

$1 \mathrm{ml}$ each of palm wine analogue and oil palm wine was dissolved in 2 $\mathrm{ml}$ of $0.1 \mathrm{M} \mathrm{HCl}$ in a test tube. To each of these, 2 drops of Meyer's reagent was added.

Saponins

$2 \mathrm{ml}$ each of palm wine analogue and oil palm wine was heated at 60

${ }^{\circ} \mathrm{C}$ for 2 minutes in a test tube.

Tannins

$2 \mathrm{ml}$ each of palm wine analogue and oil palm wine was mixed with $1 \mathrm{ml}$ of $\mathrm{FeCl}_{3}$.

\section{Cardiac glycosides}

$3 \mathrm{ml}$ each of palm wine analogue and oil palm wine was mixed in $5 \mathrm{ml}$ of chloroform in a test tube to which was added $2 \mathrm{ml}$ of conc $\mathrm{H}_{2} \mathrm{~S}_{4}$.

\section{Metallic ion determination}

Sodium and Potassium ions were determined using the method described by Basset ${ }^{14}$ while iron and calcium were determined by the method reported in Technical Bulletin ${ }^{15}$.

\section{Determination of other parameters of the wines \\ pH: This was measured for the wines using a $\mathrm{pH}$ meter (Windaus model).}

Specific gravity: A specific gravity bottle was used to determine the relative densities of the wines.

Refractive index and sucrose content: These two parameters were determined using Fisher refractometer.
Total solids: This was determined by the use of Abbe refractometer.

Ash content: $10 \mathrm{~g}$ of each of the samples was dried in an oven for 24 hours and later heated in a muffle furnace (Gallenkamp KM 106/GKP/72) at $540^{\circ} \mathrm{C}$ for 3 hours. The samples were cooled in a desiccator and later retrieved and weighed. The weights of the residues correspond to the ash contents of the wines.

Phosphorus content: This was determined by spectrophotometry and comparing the absorbance of the wines at $420 \mathrm{~nm}$ with those of standard solutions prepared $^{16}$.

Phosphorus: Palintest ${ }^{17}$ was also used and confirmed by using CECIL CE 1020 CECIL 1000 series model of UV spectrophotometry and comparing the absorbance at $420 \mathrm{~nm}$ with those of standard solutions. Standard phosphate solution was prepared by dissolving $4.388 \mathrm{~g}$ of dried anhydrous potassium hydrogen phosphate in distilled water and making up to 1 litre. $10 \mathrm{ml}$ of this solution was taken and distilled water added to it to make 1 litre of stock solution containing $1 \mathrm{mg}$ P/litre. Working standard solutions of various concentrations of $1.25 \mathrm{ppm}, 2.50 \mathrm{ppm}$, $3.75 \mathrm{ppm}, 5.00 \mathrm{ppm}, 6.25 \mathrm{ppm}$ and 7.75 ppm were prepared by diluting the stock solution with distilled water.

$25 \mathrm{ml}$ of each of the samples was filtered into a flask and to it was added 2 $\mathrm{ml}$ of $1 \mathrm{M}$ ammonium molybdate solution and 3 drops of $1 \mathrm{M}$ stannous chloride solution. A blue colour appeared and after waiting for 10 minutes the absorbance was recorded at $420 \mathrm{~nm}$ on the UV spectrophotometer. Distilled water blank was run simultaneously. The standard phosphorus solutions of different 
concentrations were processed in a similar manner. A plot of their absorbances against concentrations yielded a linear calibration graph with the given equation:

$$
\mathrm{P}=0.385 \mathrm{~A}+0.600
$$

The phosphorus (as orthophosphate) content of sample was deduced by comparing its absorbance with the standard curve and the result expressed in $\mathrm{mg} \mathrm{PO} 4$ - P/litre.

Nitrogen content: This was determined by Kjeldahl analysis and each value was subsequently multiplied by 6.25 to obtain crude protein for each sample ${ }^{18}$.

Vitamin C: The methods described by David $^{19}$ was adopted for the determination of vitamin $\mathrm{C}$ in the wines.

\section{Sensory evaluation}

Sensory evaluation of the palm wine analogue was done based on a questionnaire that was drawn and administered on twenty five habitual oil palm wine drinkers to fill after consumption of the wines placed in white glass tumblers. The samples of wines labelled (A) for palm wine analogue and (B) for oil palm wine were put in sterilized 4 litres gallons respectively from which the glass of wines were taken.

The parameters, colour, odour, effervescence, taste, balance of sweetness and overall acceptability were compared between samples A and B. The comparative assessment was based on a scale of 1 to 5 in increasing order of acceptance. The results were analysed statistically using random sampling to obtain ten habitual drinkers and t-test to determine the significance of the difference at $\mathrm{P}=0.05$ and 0.01 between the wines.

\section{RESULTS}

The results of microbiological test of palm wine analogue and oil palm wine show that no bacteria of public health significance was identified after gram staining and observation under microscope (x100 objective). Lactic acid bacteria was however identified. Yeast count was very high and noticed viable. The test for alkaloids gave negative result since there was no colour change in the wines. Frothing was not obtained in the test for saponins which showed that saponins were absent in the wines. Brown solution was not observed for the tannins test which shows that tannins were also absent in the wines. Cardiac glycosides were identified in the two samples of wines. These and the other results are presented in Table 1.

Table 1: Result of physicochemical analysis of wines

\begin{tabular}{lll}
\hline Properties & $\begin{array}{c}\text { Oil palm wine } \\
\text { (Awka) }\end{array}$ & $\begin{array}{c}\text { Palm wine } \\
\text { analogue }\end{array}$ \\
\hline $\begin{array}{l}\text { Specific gravity } \\
\text { at } 30^{\circ} \mathrm{C}\end{array}$ & & \\
Total solids & 1.0025 & 1.0239 \\
pH at $30^{\circ} \mathrm{C}$ & $2.5 \%$ & $6.0 \%$ \\
Refractive index & 3.1 & 3.9 \\
Sucrose & 1.336 & 1.342 \\
Ash content & $6.80 \mathrm{~g} / 100 \mathrm{ml}$ & $9.0 \mathrm{~g} / 100 \mathrm{ml}$ \\
& $0.40 \mathrm{~g} / 100 \mathrm{ml}$ & $0.34 \mathrm{~g} / 100 \mathrm{ml}$
\end{tabular}




Colour
Taste(Buccal cavity)
Phosphorus
Nitrogen
Iron
Calcium
Potassium
Sodium
Vitamin C
Crude protein
Alkaloids
Saponins
Tannins
Cardiac glycosides

Milky white

Sweet

$7.25 \mathrm{mg} /$ litre

$0.210 \%$

$0.2834 \mathrm{mg} /$ litre

$0.2531 \mathrm{mg} /$ litre

$0.2003 \mathrm{mg} /$ litre

$0.1934 \mathrm{mg} /$ litre

$12.3 \mathrm{mg} /$ litre

$1.31 \%$

Absent

Absent

Absent

Present
Milky white

Sweet

$4.85 \mathrm{mg} /$ litre

$0.84 \%$

$0.1984 \mathrm{mg} /$ litre

$0.2346 \mathrm{mg} /$ litre

$0.2100 \mathrm{mg} /$ litre

$0.2355 \mathrm{mg} /$ litre

$8.8 \mathrm{mg} / 100 \mathrm{ml}$

$0.53 \%$

Absent

Absent

Absent

Present

\section{DISCUSSION}

The absence of alkaloids, tannins and saponins is an indication that the wine has no toxic effects on the consumers. The presence of cardiac glycosides in the wines was expected since glucose was formed due to the fermentation of sucrose which had earlier been detected in them (Table 1). Cardiac glycosides supply the needed energy from palm wines ${ }^{20}$.
The results also showed that the $\mathrm{pH}$ of the palm wine analogue was higher than that of oil palm wine. Due to the lower acidic content, ulcer patients can also consume palm wine analogue without jeopardizing their health. The alcoholic content of the oil palm wine which was determined by distillation was also higher than that of palm wine analogue and it also gave rise to the higher acidity of the oil palm wine due to the oxidation of the alcohol.The higher

Table 2: Statistical analysis of sensory evaluation of wines

\begin{tabular}{lccccc}
\hline Attributes & $\begin{array}{c}\text { Palm wine } \\
\text { analogue } \\
\text { (mean) }\end{array}$ & $\begin{array}{c}\text { Oil palm wine Calc. } \\
\text { (mean) }\end{array}$ & $\mathrm{t}$ & \multicolumn{2}{c}{$\begin{array}{c}\text { Tabulated } \\
\mathrm{t}\end{array}$} \\
\cline { 5 - 6 } & 4.3 & 4.6 & 1.405 & 3.250 & 2.262 \\
Colour & 4.1 & 4.5 & 1.809 & 3.250 & 2.262 \\
Odour & 4.4 & 4.7 & 1.964 & 3.250 & 2.262 \\
$\begin{array}{l}\text { Effervescence } \\
\text { Taste }\end{array}$ & 3.8 & 4.5 & 2.688 & 3.250 & 2.262 \\
$\begin{array}{l}\text { Balance of } \\
\text { sweetness }\end{array}$ & 3.6 & 4.4 & 3.207 & 3.250 & 2.262 \\
$\begin{array}{c}\text { Overall } \\
\text { acceptability }\end{array}$ & 4.0 & 4.5 & 1.627 & 3.250 & 2.262 \\
\hline
\end{tabular}

value of specific gravity of palm wine analogue than oil palm wine may be due 
to the higher concentration of sucrose in the palm wine analogue.

It was found that the ash content of palm wine analogue was lower than that of oil palm wine which may be due to higher concentration of iron and calcium elements in oil palm wine as given in Table 1. Palm wine analogue had a higher total solids and refractive index and this could probably explain the lower acidic and alcoholic concentration in the palm wine analogue than oil palm wine. The palm wine analogue also contained more sucrose than oil palm wine. The presence of higher total solids in palm wine analogue than oil palm wine may also arise from the difference in the sucrose content of the wines.

The protein, vitamin $\mathrm{C}$ and phosphorus contents of oil palm wine were greater than those of palm wine analogue. The lower values of protein, vitamin $\mathrm{C}$ and phosphorus obtained in palm wine analogue are attributed to the nature of the yeast, sugar and water used in preparing the wine. The differences in the concentrations of $\mathrm{Fe}, \mathrm{Ca}, \mathrm{Na}$ and $\mathrm{K}$ for the two wines are due to the differences in the sources of the wines. The sensory evaluation comparison of the two wines showed no significant difference in the various parameters compared except in taste and balance of sweetness at $\mathrm{P}=$ 0.05 . The results imply that the palm wine analogue is almost the same as the oil palm wine and can equally be consumed as the oil palm wine. The results show that palm wine analogue can serve as a substitute for oil palm wine since there was no significant difference in the overall acceptability of the two wines by habitual consumers after sensory evaluation. All the properties of the wines assessed contributed to the quality of the wines on which the sensory evaluation depended. The oil palm trees will also be saved considerably if palm wine analogue production is encouraged. Some consumers even prefer the palm wine analogue because it is prepared under hygienic condition where flies and dust particles do not contaminate the wine. At present, an oil palm tree is not usually ready for palm wine production before the age of $8-10$ years. Palm wine tapping reduces the life span of the oil palm tree and accelerates the rate of death of the palm trees.

Palm wine analogue production will reduce deforestation of the oil palm trees. The palm trees are a good carbon dioxide sink and the depletion of the trees could lead to global warming. Every effort should be made to encourage alternative sources of palm wine in order to reduce removal of oil palm trees and the attendant environmental degradation.

\section{CONCLUSION}

Most of the characteristics of the palm wine analogue and oil palm wine assessed show that the two wines have similar properties. The promotion of palm wine analogue production will remediate the environmental consequences of palm species depletion and conserve palm forests for their economic oil production and general ecological conservation.

\section{REFERENCES}

1. Ayenor, G.K.S. and Mathew, J.S., Tropical Science 13 (1972)71.
2. Faparusi, S.I. and Bassir, O., W. Afr. Jour. Biol. Appl. Chem. 15 (1972)17. 
3. Swings, J.G. In: Steinkraus, K. H., ed., Handbook of Indigenous Fermented Foods pp. 315 - 320, Marcel Dekker Inc., New York and Basel, 1977.

4. Okafor, N., Jour. Appl. Bacter. 38 (1975)1.

5. Yanagida, F., Ichinose, F., Shinohara, T. and Goto, S., Jour. Gen. Appl. Microb. 33 (1992)501.

11. Harrigance, W.F. and McCance, M.F., Laboratory Methods in Food and Dairy Microbiology, pp. 106-107, Macmillan Publisher Ltd, London and Basingstoke, 1976.

12. Mshelia, M.S., Nuhu, A.M. and Yakubu, Y., Jour. Chem. Soc. Nig. 25 (2000) 85.

6. Levi, S.S. and Oruche, C.B., The Preservation and Bottling of Palm Wine, Research Report No 1, pp. 3-13, Federal Institute of Industrial Research, Oshodi, Nigeria, 1957.

7. Chinnarasa, E., The Preservation and Bottling of Palm Wine, Research Report No. 38, pp. 5 8, Federal Ministry of Industries, Nigeria, 1968.

8. Bassir, O., In: Steinkraus, K. H., ed., Handbook of Indigenous Fermented Food. pp. 316-317, Marcel Dekker Inc., New York and Basel, 1968.

9. Hybrid Associates, UNDP Assisted Sustainable Agriculture, Environment and Rural Development:-

Compendium of Kebbi State Environmental Laws and Regulations Part One, Volume II, Kebbi State Government, 1999.

13 Bassett, J,. Vogel's Textbooks of Quantitative Inorganic Analysis, $4^{\text {th }}$ ed., pp. 374-375, Longman Co, New York, 1973.

14. Her Majesty's Stationery Office, The Analysis of Agricultural Materials, pp. 41, 46 \& 73, London, 1937.

15. Hanson, N.W., ed., Official Standard and Recommended Methods for Analysis, The Society for Analytical Chemistry, London, 1973.

16. Palintest Ltd., Comparison of Palintest soil test methods with standard laboratory procedures, Colin Mark and Valerie agents, 1989.

17. Tinsley, J. and Nowakowski, T.Z., Jour. Sci. Food Agric. 10 (1959) 145.

18. David, N. B., Jour. Chem. Educ. 51: 7 (1974) 488.

19 Faparusi, S. I., Jour. Food Sci. Technol. 8 (1971) 206. received $17 / 6 / 05$ University, 2001. 